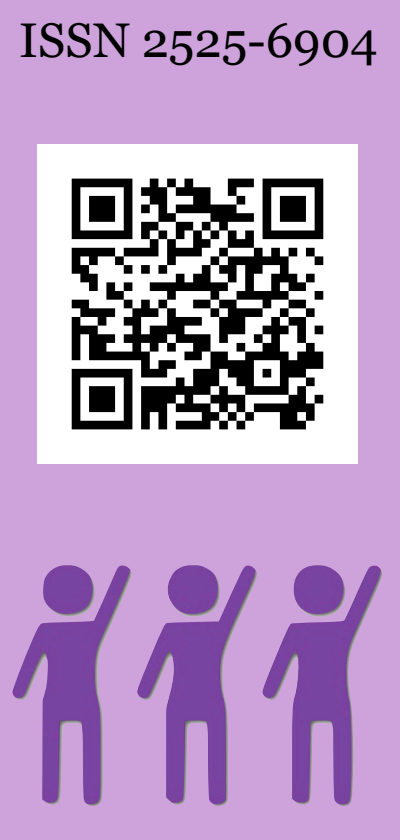

\title{
Apesar de tudo, sucesso total!
}

Ser mulher negra na política brasileira, a trajetória de Célia Sacramento

Shirlei Santos de Jesus Silva, Universidade Federal da Bahia

Bárbara Elcimar dos Reis Alves, Coletivo Lesbibahia

Felipe Bruno Martins FERnANDES, Universidade Federal da Bahia
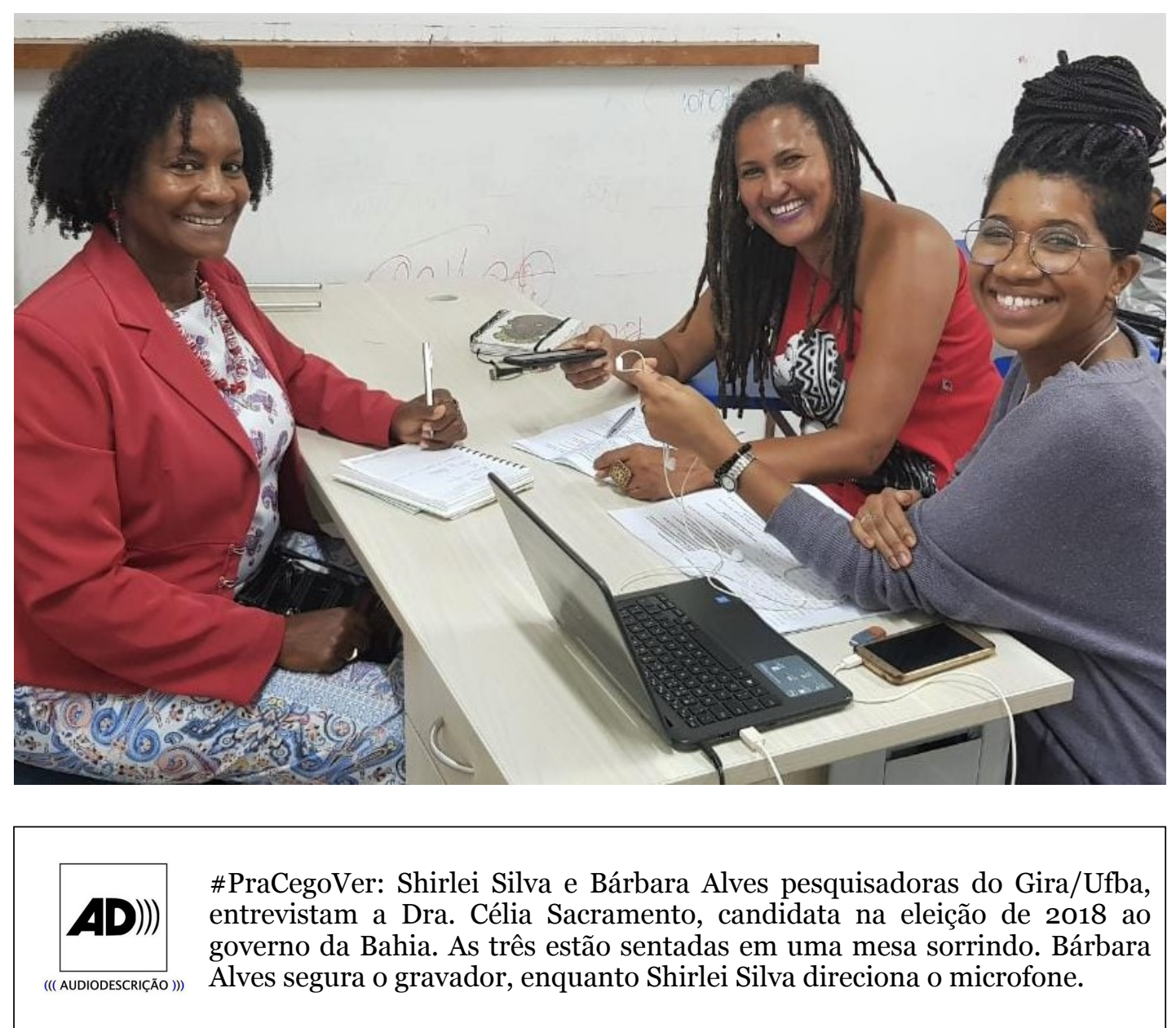

\section{\#mulherescompartido}


Em 2018, Célia Sacramento foi candidata à governadora da Bahia pela REDE Sustentabilidade. A entrevista, acompanhada por sua filha, foi realizada no dia 05 de dezembro de 2018 na Sala de Arte da Universidade Federal da Bahia (UFBA), espaço que costuma ser reservado. No entanto, tivemos que mudar de lugar pois no momento do encontro a sala estava barulhenta e com grande trânsito de pessoas. Assim, decidimos seguir para uma sala no Pavilhão de Aulas do Canela (PAC), onde encontramos uma sala vazia e com ar-condicionado, dando à entrevista a tranquilidade e conforto necessários. Montamos o computador, testamos o áudio e como ficaria a gravação final, e após tudo acertado, iniciamos a entrevista.

Foram 19 perguntas em um longo papo de duas horas, com algumas respostas mais entusiasmadas, principalmente quando falava de sua família e trajetória pessoal e outras mais sérias, quando falava da política. Por mais que o papo tenha sido leve, na $11^{\mathrm{a}}$ pergunta já estávamos todas muito cansadas, o que fez com que a segunda metade da entrevista, como verão, tenha decorrido de forma mais objetiva. Finalizamos cansadas, mas felizes pelos aprendizados e importância histórica e política daquela que se sentou diante de nós. Esperamos que essa nossa conversa traga muitas reflexões para os feminismos teóricos e ativistas em nosso país, estimulando que mais mulheres negras disputem postos elevados de liderança e poder em nosso país.

Pergunta: Conte um pouco como foi a sua infância. Onde nasceu? Onde morava? Um acontecimento histórico ou pessoal que lhe marcou?

Célia Sacramento: Nasci em São Paulo, fruto do êxodo rural. O meu pai, Gabriel de Jesus, foi para São Paulo de pau de arara no ano de 1957 a procura de trabalho. Lá ele se estabeleceu trabalhando com japoneses e também com os italianos na produção de sapatos. Essa profissão ele aprendeu em um projeto social chamado Liceu de Artes e Ofícios na cidade de Salvador, no início da sua juventude. Ele era sapateiro. Na década de 1980 ele mudou de profissão e passou a ser taxista. Já a.minha mãe, Antônia Oliveira da Silva, antes de casar ela tinha o Silva. Foi para São Paulo no ano de 1964 acompanhar a mãe dela, a minha avó Agripina Pereira da Silva, que foi visitar uma das irmãs, a tia Antônia Pereira, que já lá desde o início dos anos 1950. 
Em 1964 meu pai e minha mãe se conheceram, na época do regime militar, e se casaram. Então sou filha de pais baianos, mas nasci em São Paulo. Aos 6 anos meus pais resolveram nos trazer de volta. Eles tiveram seis filhos em São Paulo e resolveram nos apresentar para nossa família de Salvador. Depois de termos passado as férias aqui, eles decidiram que não íamos mais voltar para São Paulo. Eles voltaram apenas para vender nossas coisas que ainda estavam lá.

Lá em casa éramos como uma escadinha, um irmão atrás do outro. Meus pais tiveram seis filhos. O primeiro foi Rafael, eu a segunda, Eduardo, Gabriel, Aparecido, Suely e Roque. Esses são os filhos paulistas. Na década de 1970, quando retornaram para a Bahia, tiveram mais dois filhos, Carlos e Edson. Ou seja, tenho 7 irmãos da minha mãe com o meu pai. Depois da separação dos meus pais ganhei mais 4 irmãos, Gabriela, Samuel, Graciela e Gracilene. Como a nova esposa do meu pai, a Cleuza França, já tinha um filho, o André Luciano, minhas contas dão sempre 12 irmãos.

Assim, o início da minha vida, minha primeira infância, tudo o que eu tenho noção, apesar de ter nascido em São Paulo, é daqui de Salvador.

Eu tenho vários fatos que me marcaram muito em minha vida, mas dois deles quero destacar nessa entrevista. Primeiro uma pergunta que meu pai sempre nos fazia, todos os dias, quando a gente chegava do trabalho: "o que vocês vão ser quando crescerem?”. Em nossa casa sempre tinha essa pergunta: "o que vocês gostam?”, "vocês assistiram televisão?", "vocês assistiram o filme tal?", e então, "você viram a entrevista, o repórter?". Ele falava muito das profissões, e dizia que estudar era importante. Ele não tinha estudado, mas percebeu em São Paulo o quanto o estudo modificava a vida das pessoas. Desde o início da minha vida, eu ouvia o meu pai e minha mãe falar que entrar na universidade seria algo importante para nós, e que transformaria as nossas vidas. Ele dizia isso porque todas as suas irmãs eram trabalhadoras domésticas. A minha mãe tinha diploma de datilografia e costureira. Trabalhou antes de casar com o meu pai de costureira.

Mas eu também tinha uma tia - Terezinha Oliveira da Silva - que era professora. Ela foi a primeira professora e fundadora da Escola Comunitária do bairro da Fazenda Grande do Retiro. O pessoal da minha época, que hoje está acima dos 50 anos, todo mundo conhecia ela. Então esse fato me marcou muito. Apesar dos meus pais não saberem o que era 
a universidade, eles tinham esse sonho, de nos ver na universidade. Minha mãe fez até o ensino médio, que naquela época era colegial, não sei o nome, e o meu pai mal fez o primário. Os dois sabiam ler, mas tinham pouca escolaridade.

O segundo fato que me marcou muito na juventude, foi a separação de meus pais. Eu venho de um grupo familiar onde a união da família era muito forte. Tinha uns conflitos, mas algo que a gente não percebia muito. Minha mãe era costureira e quando ela casou com meu pai trabalhava em casa. Ela costurava, lavava roupas, essas coisas, e num dado momento eles se separaram, por causa de uma traição dele. Isso me marcou muito. Eu tinha 11 anos quando eles se separaram.

A partir dos 14 anos eu fui morar no subúrbio ferroviário de Salvador e essa mudança transformou a minha vida. Eu morava no bairro de Brotas, meu pai era microempreendedor, dono de uma sapataria na Rua do Paraíso, então meu pai tinha carro quando eu tinha 6 anos de idade. Era uma casa razoavelmente estruturada, porque naquela época era raro alguém ter televisão a cores, mas na minha casa tinha, e depois dessa separação minha mãe foi morar no subúrbio [ferroviário], em Praia Grande, na Rua Nova Aliança. Era um bairro que não tinha absolutamente nada, não tinha água, não tinha luz, não tinha nada! Não tinha asfalto! Era uma casa de um cômodo só, que não tinha nem banheiro. Eu estou falando de 1984, quando fui morar lá. E tudo isso me marcou muito porque eu comecei a ver a realidade social: eu era pobre.

Ali eu passei a ter uma vida de miserável. Percebi o que é você não ter nada. Mas isso me deu um olhar diferente, uma menina de 14 anos num bairro daquele! É tanto que meu pai que sempre acreditou muito no meu futuro, que sempre dizia "que eu ia ser sucesso total", quando fui morar no subúrbio ele desacreditou completamente. Tudo que vocês imaginarem de ruim que um homem pode pensar de uma mulher, era o que meu pai pensava que ia acontecer comigo, fatalmente porque fui morar lá. Dos 8 filhos, eu fui a primeira, porque todos nós ficamos com ele, já que minha mãe não tinha estrutura, mas quando ela conseguiu o lugar dela, eu disse: "tchau fui!" e logo depois meus irmãos me seguiram e foram viver naquela subestrutura.

Minha mãe era trabalhadora da Gallo Turismo, uma empresa do grupo Aratu. Ela era auxiliar de serviços gerais dessa empresa e tinha oportunidade de conviver com todo tipo de pessoa. Eu lembro que ela 
tinha muitas amigas do trabalho, clientes da loja... Minha mãe era de religião de matriz africana, filha de Ewá, no Terreiro de Mãe Senhora, lá de Praia Grande. Ou seja, eu sou neta de [Mãe] Menininha do Gantois, com muito orgulho! Foi aí que comecei a ter esse convívio.

Eu morei em Brotas, pois a família do meu pai é de lá, mas a família da minha mãe era toda da Fazenda Grande do Retiro. Quando eles se separaram meu pai foi morar no Parque São Cristóvão e minha mãe no subúrbio ferroviário. Então imagine, eu já conhecia a cidade por andar em Brotas e na Liberdade, na Fazenda Grande, em São Caetano, os bairros das minhas famílias. Eu conheci Matatu e Brotas na infância, e na juventude eu convivi andando nos bairros do Subúrbio e nos bairros de São Cristóvão, Mussurunga... Então eu conheço a cidade como poucas pessoas, desde muito cedo, sempre andando de ônibus. Eu conheço bem a cidade de Salvador.

Eu lembro, e Bárbara [Alves] nem sabe disso, que ela morava no São Caetano. Eu nunca fui na sua casa, mas pegávamos o mesmo ônibus, era o mesmo caminho e isso aí também me marcou. E morando nesse convívio de bairros, digo que fui salva pelos coletivos de movimentos sociais do meu bairro: o Terreiro de Candomblé, a Igreja Católica, a Igreja Assembléia de Deus, os grupos de samba. Porque esses grupos que sempre se preocuparam em envolver a juventude em coisas lícitas, passeios, atividades... Sempre tinha alguma coisa para a gente fazer, principalmente nas férias.

Eu lembro muito dos Padres da Igreja Católica. Era um grupo de cinco padres, que eles se encontravam com a gente, nos ensinavam a jogar vôlei, basquete, a nadar na praia... Então quando eu vejo essas pessoas falarem negativamente dos problemas que envolvem assédios e outros casos na igreja católica, eu tenho uma experiência positiva. Eu tenho um caso onde cinco padres liderados pelo Padre João Cara, que fizeram um trabalho muito bacana na Pastoral da Juventude daquele bairro e que ajudaram muito a gente no período da chegada das drogas em Salvador. A primeira droga foi a maconha, e era uma preocupação muito grande de todos que os jovens se envolvessem. Alguns se envolviam e eles sempre procuravam e diziam: "é mês de Maria, mês de não sei o que, a festa é de Xangô" e ofereciam uma série de atividades que mantinham os jovens como eu ocupados. Organizavam quadrilha junina, todas essas coisas foram muito fortes em minha vida. 
Na juventude eu trabalhei durante três anos, e estudei outros quatro anos para entrar na Universidade Federal da Bahia. Estudei no Colégio Comercial de Periperi, fiz o curso técnico de Contabilidade e aos 16 anos eu comecei a trabalhar como office girl na Paloma Negócios Imobiliários, uma empresa que transformou a minha vida, porque me ensinou como ser uma profissional. Essa semana eu tive a notícia de um amigo que morreu, o Miltinho Santos, que conheci no bairro do Comércio trabalhando. Eu era office girl e ele office boy. Tinham muitos outros jovens ali e eu era a única mulher e a gente se ajudava para conseguir cumprir o horário de ir para o cartório, pagar as contas nos bancos... Eu conheci ele nessa época, e lembro que a gente se encontrava ao meio-dia para almoçar na Casa do Comércio do SESC, um lugar mais barato, mas um lugar bom para conversar sobre exclusão social, sobre mecanismos para conseguir resistir ao racismo, discutir sobre Zumbi dos Palmares, visitar o estado de Alagoas, visitar o Quilombo dos Palmares... Esse era um sonho nosso naquelas conversas durante o almoço. Lembro que ele colocou o nome dos filhos em homenagem à Zumbi, coisas assim me marcaram.

Pergunta: Como foi a sua educação na infância? Você teve alguma educação religiosa?

Célia Sacramento: A minha mãe sempre foi de religião de matriz africana. Mas ela não tinha problema com as outras religiões. Fazia parte do seu cotidiano que as pessoas a convidassem para participar de todo tipo de cerimônia, e ela ia. Eram cerimônias de terreiro de candomblé, umbanda, casa espírita, centro evangélico... Sempre que chamavam a minha mãe, ela estava à disposição para ir.

Gostávamos de ir, porque todas as casas tem momentos de comida, então era assim: "dia de segunda-feira vai ter não sei o que na casa de tia Luzia”. Nós, as crianças, não gostávamos do ritual todo. Por exemplo, se o ritual começava as $14 \mathrm{~h}$ e ia até as $18 \mathrm{~h}$, a gente sabia que se chegasse às $17 \mathrm{~h}$ seria a hora da pipoca. Mas não pensem que eu era a única! A gente ia junto com todas as crianças do bairro, pesquisávamos o horário de chegar sem ter que participar de todo o ritual. E era assim em todas as casas, todas as crianças sempre participaram de todas as religiões. Meu pai não gostava porque ele não era de frequentar religião. Mas ele seguia as orientações de minha mãe, mas ele não ia, e minha mãe também era muito católica. O nome dela era Antônia, então ela 
celebrava o dia 13 de Junho. Ela frequentava a Igreja Católica, mas de forma sincrética. A criatura dava santo e também ia para a igreja católica! Então eu cresci assim, sempre no dia 13 indo para as missas de Santo Antônio, as últimas sextas-feiras do ano indo para a missa do Senhor do Bonfim.

Todos os valores nos foram passados dentro de casa. Lá na minha casa sempre houve diálogo, sempre houve debate de ideias, apesar do meu pai sempre ter sido a autoridade máxima. Mesmo assim, a gente sempre conversou. Eu lembro muito dos ditados que ele dizia: "quem se mistura com porcos, farelo come", "digas com quem tu andas, que te direi quem és", coisas do nosso cotidiano. Mas tem algo que me marcou muito, que é a questão da leitura. Eu sabia que teria que fazer faculdade. Meu pai trabalhava, tinha loja aqui no Paraíso, então era perto do Colégio Central. Os jovens quando iam consertar sapatos, ele perguntava: "você está lendo o que aí?". Eu lembro do primeiro livro que eu li com 9 anos, Capitães de Areia. Aconteceu o seguinte: ele perguntava o porquê dos jovens estarem lendo aquele livro e eles respondiam "que ia cair no vestibular". Era o suficiente para o terror acontecer lá em casa, o meu pai chegava: "eu já li o livro tal, é um livro muito importante, vai cair no vestibular, vestibular é uma prova para poder entrar na universidade, então vocês vão ter que ler". Minha mãe lia, então minha mãe lia no horário que ela podia, ai quem chegava primeiro, pegava o livro e lia também e a noite a gente fazia um reconto para ele. A gente fazia um reconto para minha mãe e para meu pai. Para minha mãe não era nem um reconto, a gente discutia, porque ela estava lendo também. Com meu pai a gente contava porque ele nos tinha dito que já tinha lido.

Até que no dia da minha formatura eu descobri que ele nunca tinha lido. Eu me considerando livre de tudo, marquei com namorado para sair para uma noitada e meu pai me disse que precisava conversar sobre algo muito importante: "o problema é o seguinte minha filha, eu passei um constrangimento nessa sua formatura, os professores te elogiando". Disseram ao meu pai que eu tinha sido a melhor oradora, que eu tinha sido uma ótima estudante. E eu sempre falava para todo mundo que era um legado, que sempre me encontravam com um livro na mão por conta do meu pai. Que tínhamos que ser rápidos na leitura para passar o livro para os outros irmãos. Porque tínhamos apenas uma cópia do livro, e que meus pais liam e a gente tinha que fazer o reconto. E aí meu pai vem e me diz "não minha filha". Quando me perguntavam sobre 
um livro eu dizia: "esse foi meu pai que me indicou". Ele então me disse para desmentir tudo isso: "sabe o que eu fazia? Passava no Sebo, ali na Rua Chile pegava o livro, lia o nome, depois a orelha, chegava em casa e dava uma ênfase e depois dizia que não ia mais contar". Foi assim que a gente leu toda a coleção da série Vagalume, Jorge Amado, o que vocês imaginarem, e foi assim que consegui minha bolsa para estudar lá com Jorge Portugal. Isabel Reis e eu éramos bolsistas, porque a gente tinha toda essa literatura na bagagem. Isso ajudava na aula. Então os valores que recebemos em casa sempre foram muitos.

Eu lembro quando comecei a trabalhar com 16 anos e o meu pai dizia, "onde se come o pão não se come a carne. Célia, primeiro a roupa". Acho que desde que Barbara [Alves] me conhece, eu visto o mesmo traje. Sempre usei terno, calça, sapato fechado, porque fui uma pessoa muito bonita. Nunca tive dúvida disso, tanto que até hoje não uso maquiagem. Aliás, vou fazer um curso de maquiagem esses dias, já que eu já fiz 50 anos, tenho que dar um tchan, mas eu nunca precisei. Então sempre tive essa forma de vestir, sempre usei o cabelo preso, as vezes para atrás porque tinha muito cabelo, mas preso, exatamente para evitar o assédio. Minha mãe era muito cuidadosa com isso, e sempre perguntava “como é que estão as relações de trabalho?”. Ela dizia para eu ter muito cuidado com essa questão, era uma discussão mesmo, qualquer olhar, qualquer coisa que percebesse de diferente, teria que dizer a ela. A mulher naquela época era zangada, então sempre andei de cara fechada, a vida toda, sempre andei de cara fechada. Acho que passei a abrir os dentes depois que a minha filha Keila nasceu. Porque Keila é risonha, mas sempre fui uma pessoa fechada, exatamente para evitar assédio, por causa desse ditado: "onde se come o pão não se come a carne".

Pergunta: Você pode nos contar um pouco sobre a sua formação acadêmica e profissional? Onde começou a estudar? Quais as pessoas que te marcaram durante sua vida escolar?

Célia Sacramento: Estudei no Coronel Sebastião Dias, minha primeira escola. Mas já entrei na escola alfabetizada. Escrevo com a mão esquerda e na minha época isso era um crime, toda criança tinha que escrever com a mão direita, e os professores amarravam as mãos das crianças, para escreverem com a mão direita. Minha mãe achava lindo eu 
escrever com a mão esquerda. Então minha mãe alfabetizou meu irmão mais velho, o Rafael, e eu primeiro, antes da gente ir para a escola. Fomos alfabetizados num papel de pão!

Quando cheguei na escola minha mãe dizia "Célia, você faz o seguinte, a professora vai colocar o cabeçalho", minha mãe já tinha modelo porque o primeiro filho estudava, então tudo que meu irmão fazia na escola quando ela chegava para ensinar o dever para ele, ela me chamava: "Olha Célia, você tem que aprender isso aqui, porque no ano que vem, vai ser isso aqui, a mesma professora, a professora Vera, então tem que escrever, tem que copiar". Assim, no primeiro ano, a minha mãe dizia, "a professora não pode ver que você é esquerda". Então treinávamos o jeito que eu ia copiar a matéria. Lá em casa não tinha quadro, a gente utilizava as paredes, enquanto todo mundo brigava com os filhos por riscarem as paredes, lá em casa nunca foi problema, podia riscar mesmo, "depois pinta", dizia minha mãe. E ela falava, " $a$ professora vai escrever no quadro e quando ela colocar o ponto final sinalizando que acabou, você tem que acabar também”. Mas aí tinha um problema, se eu acabasse e todo mundo ainda estivesse começando a ler, eu ia acabar abusando na sala, ou seja, ia conversar pois sempre fui muito hiperativa. Então acabar antes de todo mundo também era um problema!

Praticamente toda semana eu era expulsa da sala. "Essa menina é impossível", dizia a professora. Ao mesmo tempo eu acertava tudo e fazia todas as atividades. Assim a professora Vera teve uma ideia, me colocou como uma espécie de monitora, líder da sala. Desde a primeira série até a faculdade, sempre fui a líder da turma por causa disso, porque tinha um up a mais em relação aos colegas. Minha mãe acompanhou os nossos estudos até a sétima, oitava série, quando eu tinha por volta de 14 anos. Nessa época minha mãe trabalhava em casa, ela não trabalhava na rua. Ela só veio trabalhar na rua depois, quando meus pais se separaram.

As pessoas que marcaram a minha juventude foram a minha mãe, que me ensinou a ler e escrever, e as professoras que tive. Não consigo lembrar o nome de uma professora que tive no bairro de Brotas, que também me marcou muito, ela era vice diretora da escola. Importante lembrar que todas as vices da minha época eram negras, e as brancas sempre foram as diretoras. Então na $3^{\mathrm{a}}$ série eu fazia parte da banda da escola e lembro que iam organizar o desfile da primavera. $\mathrm{O}$ desfile envolvia a escolha da rainha e tinha também a rainha do milho. A primeira vez que escolheram a rainha, eu lembro que era uma 
coleguinha da turma com o apelido de Coquinho, de tão branquinha que era e com os olhos claros. Já no segundo ano primário a diretora estava doente, então quem fez a seleção foi essa vice que sempre trabalhava à tarde. Ela assumiu a diretoria durante a doença da diretora, também pela manhã, trabalhando nos três turnos. Ela mudou o critério de seleção e perguntou, "quem tem um vestido longo branco? Sapato? Cabelo grande?”. Ela criou outros critérios e selecionou coleguinhas negras. Mas quando a diretora descobriu que a rainha do milho e da primavera seria uma menina negra, não aceitou e escolheu duas princesas brancas. A Rainha do Milho e da Primavera negra era eu. Então enquanto existem muitas histórias de meninas negras que nunca foram rainhas do milho e da primavera, posso contar que fui Rainha do Milho e ainda Rainha da Primavera. Quando a diretora branca descobriu foi uma briga, chamaram toda a minha família, meu pai, minha mãe, meus tios, para falar que já havia ocorrido uma outra seleção. Mas aí subiu a vizinhança toda e não teve jeito.

Minha história com a Contabilidade começou com o meu tio Agnaldo Ciryno da Costa. Na minha época todos os jovens, inclusive eu, queriam estudar na escola técnica, no ensino médio, porque escola técnica, segundo acreditávamos, garantia empregabilidade. ,Mas meu tio boicotava essa minha ideia. Ele dizia, "minha filha, quem faz química e vai trabalhar no polo, vai ganhar bem, mas se tiver 10 anos de vida, 5 anos fica com Polo. Os homens ficam com impotência sexual, as meninas são assediadas pelos chefes. Então não é um ambiente para você. Faça contabilidade, registre documentos, negócio de escritório". Então esse meu tio foi uma pessoa que me marcou muito, pois me ajudou a decidir a minha profissão. Ele foi o primeiro presidente do Sindicato dos Oficiais de Justiça da Bahia, um homem negro.

Uma outra pessoa muito querida que me marcou foi a minha tia Terezinha, esposa do tio Agnaldo. Ela foi a primeira professora de uma Escola Comunitária no nosso bairro, a Escola Nossa Senhora da Conceição. Minha tia, quando escutava os relatos das mães em relação a briga com os maridos, fazia com que os meninos ficassem na escola por mais tempo. Lembro que as professoras tinham um papel muito importante em ajudar as mães que eram vítimas de violência doméstica. Os meninos viravam nossos parentes. Acho que é por isso que tenho vários "primos" pela cidade. Tenho até irmãos como o Evandro Calixto. Todo mundo pensa que o Evandro é meu irmão de verdade, mas nunca foi! Isso veio por causa dessa relação com a escola Nossa Senhora da 
Conceição. Essa minha tia ela me ensinou a combinar cores de roupa, roupa com o sapato, e todas as vezes que olho para o meu guarda roupa para escolher algo, é como se ela estivesse me orientando na roupa. Mas tem também a minha mãe. Por exemplo, se for segunda-feira ou sextafeira e eu pegar uma calça preta, vem minha mãe na hora e diz, "hoje é sexta-feira, você tenha paciência". Eu tiro a roupa na hora! Eu escuto elas falarem. Esses são os valores que ficaram na minha memória e nas minhas práticas.

Pergunta: Quais eram seus ideais? Que pessoas influenciaram você positiva ou negativamente?

Célia Sacramento: Eu queria trabalhar para ajudar a minha mãe. Meus pais tinham se separado. Minha mãe ganhava o saláriomínimo, era muito sacrifício para ela. Ela queria sustentar todos os filhos e sabia que tinha dificuldade. Meus irmãos ajudavam, meu pai ficava possesso da vida! Não nos faltava nada, mas meu pai dizia, "vai morar no subúrbio e faz com que meus filhos trabalhem carregando compras, ajudem na casa”. Assim, comecei a trabalhar com 16 anos como office girl e disse, "preciso garantir o meu emprego". Lembro de abrir o jornal e ler os anúncios, "precisa-se de auxiliar de escritório, auxiliar de contabilidade, contabilidade geral”. Lembro de pensar que nessa área não tinha perigo e que iria me apaixonar pela Contabilidade. Foi assim que tomei a minha grande decisão de ser contadora, porque eu não ia, de jeito nenhum, ficar desempregada.

Quando comecei a estudar Contabilidade, descobri que era uma área de conhecimento que toda hora muda. Eu pensava, "gente, é muita legislação"! Como sou uma pessoa dinâmica e faço várias coisas ao mesmo tempo, pensei que isso seria um ponto positivo para essa área. Descobri então que uma legislação vigente num ano, vai mudar no ano que vem! Então comecei a tomar cursos, às vezes até de graça, no ano anterior. Fosse um curso que o conselho de contabilidade oferecia, as vezes um curso pago. Eu me esforçava. Nunca abri mão de comprar um livro, até mesmo parcelado. Eu fazia caixa para comprar um livro importante! E isso desde o ensino médio! Hoje eu tenho um quarto cheio de livros, sempre investi muito em livros. Eu também lia por lazer. Minha mãe ficava preocupada porque eu lia muito revista em quadrinhos. Até hoje! Quando os meninos eram pequenos, eu dizia 
assim, "vou comprar para a galerinha toda". Antes eu dava uma lida, depois passava para as crianças. Até hoje sou muito fã de revista em quadrinho, compro, leio e dou para as pessoas. Todos os meus parentes do lado de minha mãe eram leitores.

Lembro especialmente de meu tio Alguedes de Jesus, que tocava violão, e ele também me marcou muito. Foi assim que me integrei com o pessoal da Igreja Católica, com o padre Teófilo e o padre João Cara. Eles também tinham um violão. Decidi aprender a tocar violão. Quando fiz 15 anos minha mamãe comprou meu primeiro violão. Imagine, ela comprou parcelado em 10 vezes! Um violão hoje custa em torno de $\mathrm{R} \$ 200,00$. Naquela época fazer essa compra com dez parcelas de $\mathrm{R} \$ 20,00$ era pesado no orçamento familiar. Tenho até hoje esse violão, um Giannini. É um bom violão! Minha mãe não comprou qualquer violão. Assim, aprendi a tocar violão na juventude. Mas nunca quis ser da música ou seguir carreira artística. Tenho essa voz grossa e se eu tivesse feito aula de canto, talvez poderia ser cantora. Era a época que Margareth Menezes estava começando e eu pensava, "esse pessoal não consegue se sustentar, todo mundo só vive reclamando que não tem dinheiro, não quero não", queria tocar violão para mim.

Outra pessoa que me marcou foi o empresário Arivaldo Figueiredo Nicory, que era meu chefe, marido de Rosa Noblat. Rosa era a gerente da Gallo Turismo, a empresa onde minha mãe trabalhava.Ele me ensinou como ser uma profissional. A questão da pontualidade, de cumprir os prazos... Eu já vinha com a disciplina da minha casa, ter palavra, pois na minha família se alguém disser que vai fazer algo, tem que fazer, porque se comprometeu. Eu e meus irmãos tínhamos essa disciplina que aprendemos com meu pai e minha mãe. Mas nesse primeiro trabalho aprendi que isso também é muito importante no ambiente profissional. Todo mundo sabe que tenho o pavio curto. $\mathrm{Na}$ minha casa éramos seis homens e duas mulheres, eu e minha irmã. Como o sistema é machista, então a tendência é um prejuízo total para as meninas. Minha sorte é que meu pai era um pouco feminista para a época. Ele dizia, "olha, todo mundo tem que fazer tudo igual, a pior coisa que existe é homem não saber fazer nada". Eu cozinho bem, mas todos os meus irmãos cozinham melhor e adoram cozinhar, por exemplo. Quando minha mãe ia ter os filhos, meu pai ficava em casa e cozinhava. Ele fazia as coisas, ajudava meus irmãos... Assim, a gente desde muito cedo aprendeu que cada um tem que lavar a própria roupa, fazer a sua parte no ambiente doméstico. Então eu já tinha essa disciplina de casa. 
Mas no ambiente de trabalho, quem me ensinou muita coisa foi o Arivaldo.

Tem também aquelas pessoas que me marcaram negativamente. Quando fiz o primeiro vestibular minha nota foi 4,6. Mas a média naquela época para entrar na universidade era 7. Apesar de ter uma boa média no ensino médio, minha nota não foi suficiente. Fiquei muito mal e pensava, "meu Deus, não aprendi nada na escola". Decidi entrar no cursinho pré-vestibular do Colégio Ideia e ficava o dia inteiro ali no Politeama. Esse cursinho existe até hoje. Eu trabalhava durante o dia e estudava lá a noite. No segundo vestibular que tentei minha nota foi 6,7 . Fiquei triste, mas alegre porque pulei de 4,6 no ano anterior para 6,7. Até comemoramos! Imagine você, eu ganhava um salário mínimo e pagava o meu transporte para o cursinho. Essa história de patrão pagar o transporte só veio com a Constituição de 1988, porque antes disso a empresa não tinha que pagar o transporte e também não existia a meia passagem de estudante, não tinha nada. Então minha mãe pagava o meu transporte e metade do salário mínimo que eu ganhava era para pagar o cursinho.

Na minha juventude teve até um momento que fiquei um pouco rica, quando fui estagiária da Caixa Econômica Federal! Lá eu ganhava três salários mínimos e a minha mãe ganhava um. Foi uma transformação na nossa vida, a gente comprou um monte de coisa para a casa, fez reforma e tudo. Mas só fiquei 6 meses pois não quis renovar o meu contrato quando percebi que trabalhar num banco é fazer todo dia a mesma coisa e que tudo o que aprendi na primeira semana como estagiária não tinha mudado nos seis meses! Pensei, "estou fazendo o curso técnico de contabilidade, que tem uma área fiscal, então vou ficar no escritório onde já trabalho como office girl". Quando entrei como estagiária na caixa, trabalhava no turno da manhã no banco, à tarde no escritório e por volta das $18 \mathrm{~h}$ ia para o SESC, onde eu treinava vôlei até umas 19h. Pegava 45 minutos de ônibus e chegava no cursinho, onde ficava até 22h3omin. Então saia correndo para não perder o ônibus do horário na Lapa.

No terceiro vestibular a média para entrar continuava 7 e a minha nota foi 8,3 . Só que não passei e descobri que na verdade eu estava concorrendo com os alunos que tinham estudado nas melhores escolas e tinham as melhores alimentações. A média que eu tinha tido na escola também entrava na avaliação da universidade, o que fazia com que eu precisasse tirar uma média acima de 8,5. Quem não tinha uma 
média acima de 9,0 não adiantava nem tentar. Assim que você entende a importância das cotas. Eu estava estudando para alcançar a média 7, consegui 8,3 , mas eu não tinha a condição social de concorrer, pois os concorrentes tinham as melhores alimentações e as melhores escolas. Nesse período entrei em depressão profunda, um negócio que só quem passa sabe. Mas depressão de pobre dura dois dias. Não podemos ficar muito tempo parados. Minhas amigas diziam que eu tinha que pagar as contas, tinha que ajudar os meus irmãos. Tive que superar e me perguntei, "que vou fazer?". Minha mãe dizia, "menina você vai conseguir!".

Nesse momento a minha vida já tinha se transformado. Eu já ganhava dois salários mínimos e meio! Já podia fazer o ritual daquela época: arranjar um namoradinho, casar, ter um filho... Eu já tinha a perspectiva de ganhar mais se aprendesse mais da contabilidade. Mas eu queria descobrir o que era a tal da faculdade! Tinha algumas amigas na escola que falavam, "mas Célia, você é uma menina tão simpática! Porque você não arranja um namorado que tenha caráter $e$ personalidade, a forma delas de falar que ele tinha carro e dinheiro. Esse negócio de estudar não é para preta e pobre não! Você é maluca, é? Está é perdendo tempo. O dinheiro que você gasta pagando cursinho, poderia estar comprando roupa de marca". Eu nunca usei roupa de marca. Tinha um tênis para o ano inteiro e cinco cadarços de cores diferentes, para combinar com a blusa. Cadarço vermelho, cadarço amarelo, blusa vermelha, blusa amarela, e o tênis era branco. Uma moda que a gente de comunidade tinha, era o ano todo essa roupa para trabalhar e para ir para o cursinho de noite, e também para usar no final de semana. A gente tinha uma roupa diferente para ir para uma festa. Por exemplo, quando começava a época de dezembro, com a festa de Santa Bárbara, então minha mãe, que era costureira, fazia uma bermudinha com uma blusinha, uma coisinha de babado, fita... Tive algumas amigas que me colocavam para baixo, dizendo "esse caminho, essas escolhas que você está fazendo, não são boas".

Uma amiga, que é a minha comadre até hoje, madrinha do meu filho, madrinha do meu casamento, Isabel Reis, professora doutora, me motivava. Se eu estava no quarto vestibular, ela devia estar no quinto. Ela estudou no Águia, queria fazer comunicação, e olha que comunicação naquela época era o curso mais concorrido! Mais até do que Direito e Medicina! Não tinha na Universidade do Estado da Bahia (UNEB), era só na Universidade Federal da Bahia (UFBA). Já o curso que eu queria, o 
bacharelado em Ciências Contábeis, começou na UNEB em 1989. Tanto que no ano que passei, passei na UNEB, UFBA e na Visconde de Cairu. $\mathrm{Na}$ Católica eu perdi, por causa do inglês. E foi o primeiro resultado que vi, tanto que fiquei triste, me desmotivei, achei que tinha perdido nos outros também. Aí os resultados foram publicados nos jornais. Até hoje tenho os jornais guardados das minhas aprovações nos vestibulares. E Isabel, essa amiga que é muito próxima, uma irmã, me motivou muito. Como nós duas éramos arrimo de família, quando uma desmotivava, a outra motivava e ela foi muito importante para mim nesse momento. $\mathrm{O}$ Valdemir Menezes, um amigo do nosso bairro, que já tinha sido meu namorado, e depois virou amigo, ia sempre com a gente para o cursinho. Foram os dois, Isabel e Valdemir, que me disseram que eu estava no caminho certo enquanto todo mundo dizia que eu estava fazendo o investimento errado.

Ná época do cursinho, nós três nos preocupávamos uns com os outros. Nesse momento nos descobrimos, vários jovens negros, com os mesmos problemas. Então a gente se ajudava. O dia que eu tinha dinheiro, comprava pão para nós numa padaria em frente ao cursinho. Combinávamos sobre quem ia comprar a manteiga. Cada um fazia uma coisa. Tinha um rapaz que vendia pipoca e lembro que ficava na escada esperando ele acabar de vender a pipoca para me dar um saquinho. A Isabel e um outro amigo, que também é professor doutor, o Zé Roberto, José Roberto Fontoura, ficávamos juntos na escada, sonhando, olhando para as estrelas. A nossa alegria era pensar que tudo estava bem, dizíamos, "a nossa estrela nasceu para brilhar". "Eu te vejo auditora do Tribunal de Contas", ele me dizia. Ficávamos sonhando sobre o que faríamos e o que queríamos ser.

Eu e meus irmãos sempre terminávamos o ano escolar cedo, pois nunca ficávamos na recuperação. Mas aí não tínhamos com quem brincar. A orientação de minha mãe é que ajudássemos nossos colegas. Então desde sempre ensinamos, dávamos aula, e isso foi algo que a gente sempre fez junto. Gostávamos disso pois assim liberávamos todo mundo para podermos brincar juntos. Assim comecei desde cedo a dar aulas, mesmo que fossem de brincadeira. Todos os sábados a turma do cursinho pré-vestibular se encontrava na Biblioteca Central dos Barris. A gente sabia quem tinha pego um livro que precisávamos emprestado, por exemplo. Então quando a gente via aquela pessoa na estação da Lapa pedíamos que devolvesse o livro. A gente começou a gostar desse ambiente da biblioteca central. Quando dava meio-dia, o pessoal 
colocava a gente para fora da sala, mas depois de tanto a gente reivindicar, a biblioteca passou a ficar aberta no sábado o dia todo. A gente estudava os assuntos do vestibular, falava da religião de cada um, onde tinha festa, convidava um e outro. Nas festas, só os evangélicos não iam! Assim a gente começou a falar sobre racismo.

Tínhamos um livro de bolso: $O$ que é racismo?, do Joel Rufino dos Santos, da coleção Primeiros Passos. Líamos também, da mesma coleção, “O que é sociologia?”, que um namorado me emprestou pela primeira vez. Lembro que um dia discutimos o livro, "O que é filosofia?" e descobrimos que éramos uma juventude negra com os mesmos ideais. Tinha um editor de um grande jornal de Salvador que escrevia uma coluna sobre juventude, mas que só abordava como os jovens eram violentos e nunca o que ocasionava essa violência. Eu levava a semana toda com aquele material e no sábado a gente se reunia para discutir. Sistematizávamos nossa discussão e tínhamos até a terça-feira para datilografar e produzir uns mosquitinhos que distribuíamos na terça da benção à noite. Geralmente protestávamos essa coluna.

Assim, nossas discussões passaram a ser além dos nossos desejos de carreira profissional e começamos a pensar em quem ia assumir essa cidade negra. Pensávamos que não tínhamos o poder, e que não adiantava o movimento negro falar e gritar que queriam poder, se ninguém estudava ou era qualificado para assumir o poder. A gente pensava assim naquela época. Que se a pessoa quase não tivesse qualificação, teria que estudar para tomar o poder. Lembro que eu dizia que estava tudo bem e que eu seria a mulher do dinheiro, que financiaria as campanhas. Eu já dizia naquela época que não teria problema nenhum em trabalhar com a direita, desde que permanecesse defendendo as nossas causas, compondo equipes e definindo quem seriam as pessoas que iam trabalhar comigo. Que eu faria uma seleção por cor, mesmo que essas pessoas não tivessem ideologia racial. Eu pensava assim.

Pergunta: Como descreve político e socialmente a Bahia e sua relação com o restante do País?

Célia Sacramento: Eu entrei na política partidária quando cheguei do doutorado em 2005. Num domingo, no início de fevereiro de 2006, um grupo do movimento social, de uma entidade do município 
que insere jovens afrodescendentes na universidade, o grupo da gestão atual, foi na minha casa e me convidou para ser o novo nome na política da cidade. De 2006 para cá muita coisa aconteceu. Percebo que houve um avanço nas políticas de promoção da igualdade racial, na questão dos direitos da mulher... Mas quando o quesito é a mulher negra, nós continuamos invisibilizadas. Tudo evoluiu, tudo avançou, menos as questões voltadas para a mulher negra. Nada aconteceu para atingir esse público, que ainda espera o acolhimento do Estado. A política de cotas, por exemplo, não resolveu a questão das mulheres. No contexto geral nós conseguimos alguma coisa, um enegrecimento um pouco maior da sociedade, em um ou outro setor, mas isso não atingiu as mulheres negras.

A Bahia conseguiu construir o combate ao racismo institucional na Prefeitura Municipal de Salvador. E posso falar disso porque fui viceprefeita da cidade. Falo com conhecimento de causa. Nós conseguimos, construir o Centro de Referência LGBTQI+. Essas discussões avançaram, mas a materialização disso não se concretizou. O que nós temos é uma onda de violência muito grande, uma quantidade enorme de jovens que têm morrido. É algo assim assustador! E esses jovens são negros. Toda política que foi construída nesses 30 anos que nós temos lutado por cotas e tudo o mais não deu conta da juventude. A minha juventude já era exterminada, a sua juventude ainda é exterminada. Então me preocupo muito com essas duas agendas: a da mulher e da juventude.

Considero que a juventude sempre foi aguerrida. Mas os homens e outros setores, quando saem da faculdade e entram no mercado de trabalho ou então se casam, saem da luta. As mulheres negras não, estão o tempo todo na luta! É marcha de mulheres toda hora, sempre a criação de um grupo de mulheres novo... E a gente não conseguiu nosso avanço, você sabe por quê? Falta de representatividade de mulheres na política! Nós mulheres negras, mesmo sendo maioria, não conseguimos entender que só transfaremos nossas vidas quando tivermos representatividade. As vezes acho que a gente não consegue entender isso. Como é que as pessoas olham para mim e me execram porque eu fui vice de ACM Neto? Eu digo, "olha gente, mais Rui Costa tirou Lídice e colocou Coronel"! Mesmo assim todo mundo votou nele porque ele é branco. A Dilma fez aliança com Temer, que tirou ela, e quem indicou Temer foi Lula e isso pode, todo mundo apoia. Eu percebo que não nos unimos para dar peso na política. Vivemos batendo umas nas outras, nunca estamos na mesma filosofia. Essa semana fui para um evento no teatro com a minha filha e 
as mulheres diziam "uma dá a mão para a outra, ninguém solta a mão de ninguém". Aí eu perguntei, “isso aí é teoria, não é?". No mundo da política as mulheres também brigam entre si, competem, para mim isso é algo sem nexo.

Quando decidi ser vice-prefeita com ACM Neto já me sentia realizada, sem nem começar o processo eleitoral. Pautei que naquele momento iríamos priorizar a pauta racial na cidade, que nunca teve. Ele me questionava, "como é? Nada a ver". Eu dizia que ele estava por fora, que não acompanhava o que estava acontecendo. Ele me dizia que não teríamos pauta racial, mas inclusão social. Lembro também que o Pelegrino já tinha o vice dele, que era um homem branco. Nessas eleições todo mundo já estava resolvido. Mas quando ACM Neto anunciou que eu seria sua candidata à vice, quinze dias depois o Kertész colocou uma pessoa negra como vice, Pelegrino teve que mudar a chapa dele, chamou a Olívia Santana. Foi eu que iniciei esse movimento. Planejei e pensei. Lembro que pensava assim, "a pauta racial vai entrar agora" e ninguém conseguia entender isso. Eu dizia para o ACM Neto que se eu ou a Olívia Santana ganhássemos seria a mesma coisa.

Não preciso de política para viver. Sou funcionária pública federal e do estado. No plano pessoal tenho a minha empresa desde 1993. Mas acredito que não adianta você se resolver no plano pessoal e não resolver o plano coletivo. Tenho família, então estou falando de uma questão de sobrevivência coletiva. Meu filho estuda na Faculdade de Engenharia da UFBA, é negro. Entrou sem cotas, pois vinha de escola privada e perdeu esse direito, mas foi um dos primeiros colocados. A minha filha mal entrou na universidade e já estava debatendo sobre essas questões com as professoras, mestres, doutores, estudantes de graduação... Essa juventude tem uma pegada diferente. Aprendi ao longo da minha vida que nós temos que avançar a partir da educação, mas para isso temos que nos unir, pois a falta de união é o que nos exclui.

Pergunta: Como você entrou na vida política?

Célia Sacramento: Aos 17 anos, quando minha mãe participou do grupo que fundou a associação do bairro, eles chamavam os jovens para ajudar a limpar a sede da Associação, a pintar, organizar as cadeiras para as reuniões. Mas quando a gente queria usar o espaço da associação para uma festa, eles não deixavam. A gente começou a questionar 
porque: "a diretoria não libera, a diretoria não deixa a gente fazer nada". Começamos a nos perguntar como poderíamos nos tornar diretores e decidimos que faríamos parte da diretoria da associação do nosso bairro. Acho que a política está aí. Fizemos um movimento no bairro, ganhamos, mas nossa chapa foi impugnada pois todo mundo era menor de idade. Mas os adultos deixaram a gente fazer o movimento. Mas lembro do meu pai dizer,"Célia, para conseguir as coisas tem que dialogar”.

Nós montamos um grupo de juventude negra, em que um ajudava o outro com os conteúdos mais difíceis, e nesse trabalho fundamos uma cooperativa de professores. Tinha como objetivo ajudar jovens a entrarem na universidade. Funcionava assim: todo mundo dava dinheiro para ajudar, para pagar o aluguel, a estrutura, então primeiro era uma cooperativa só entre eu e meus amigos, depois com a juventude negra. Só que esses jovens negros tinham um ideal! Nós não queríamos legalizar o grupo, nem como juventude negra, nem como cooperativa, pois temíamos a volta do regime militar. E achávamos que se fôssemos um grupo legalizado o governo estaria com a nossa vida nas mãos, teria a nossa ficha. Mas tinha um grupo que queria legalizar, porque era a única forma de conseguir captar recursos para fortalecer a entidade. Como eu era contadora, então a pessoa hábil para fazer isso, os contatos para conseguir pessoas para ajudar nesse processo, negros bem sucedidos para ajudar a cooperativa... Depois virei a contadora da cooperativa. Quando saí da Bahia para cursar o mestrado na Universidade de São Paulo (USP), a minha empresa continuou fazendo a contabilidade da entidade. Essa empresa que montei em 1993. Inclusive me casei com o meu sócio dessa empresa, tivemos dois filhos e ficamos como os contadores, que depois mudou de nome, virou associação. Hoje é uma importante entidade que insere jovens afrodescendentes na universidade em Salvador, e eu fui a primeira contadora da entidade. Apesar deles não gostarem que eu fale dessa história real, a entidade antes de se tornar Instituto era uma cooperativa e os líderes de hoje nem faziam parte naquela época. Os fundadores fomos eu, o Jadir, a Maísa, o Osmário, a Carmen e muitos outros. A pessoa que é a liderança hoje apaga essa história, nem lembra que existimos.

Pergunta: Por quais partidos políticos você já passou? 
Célia Sacramento: Na Juventude eu militei no Partido dos Trabalhadores (PT), apesar de nunca ter me filiado. Sempre apoiei Creuza Oliveira, do sindicato das trabalhadoras domésticas, quando ela era do PT. Também acompanhava a Olívia Santana, do Partido Comunista do Brasil (PCdoB). Eu apoiava os candidatos no bairro da Fazenda Grande do Retiro, com o grupo da juventude da Vila Natal. Nosso candidato naquele bairro era o Luiz Alberto. Eu não lembro se foi em 1984 ou 1986 que o Luiz Alberto e a Luiza Bairros, ela Deputada Estadual e ele Deputado Federal, saíram candidatos e fui uma das pessoas da juventude que saia às $11 \mathrm{~h}$ da noite para pichar os muros do bairro. Foram as primeiras candidaturas que apoiei na minha vida. $\mathrm{Eu}$ nem votava, tinha 16 anos, mas saia para pichar. Naquela época não se tinha dinheiro para papel, então a divulgação das candidaturas era nos muros do bairro. Também militei no Grupo Álcool-Íris lá no Curuzu, com Bartho, Suzete, Edson Bonfim, Antônio Raimundo... Tínhamos reuniões do samba com o Alírio. Só de vez em quando minha mãe deixava eu ir para a Senzala do Barro Preto, pois as atividades aconteciam muito tarde. Sempre fui militante, desde muito jovem.

Minha primeira candidatura foi em 2008, quando me filiei pela primeira vez em um partido político, o Partido Verde (PV). Fui candidata a vereadora, e todo esse grupo que citei acima do movimento social me apoiou. Fui convidada para me candidatar e precisava me filiar. Fiquei na suplência de vereadora, eu era a primeira suplente do PV. Foi naquela época que estourou o mensalão, expulsaram a Heloísa Helena. Sempre fui fã dela, e sempre gostei da forma que ela se posiciona. Tive a oportunidade de conhecê-la em um Encontro de Mulheres em Minas Gerais. Fiquei encantada pela mulher que ela é, mulher de verdade, e pensei, "meu Deus, vejo pela televisão, a televisão faz questão de mostrar aquele momento raivoso dela, mas ela é um doce de pessoa". No Encontro de Mulheres a vi chorando com a gente.

As vezes acho difícil ser do movimento negro, pois apesar de ser uma pessoa forte, quando estou com o movimento me enfraqueço. Porque estou sendo avaliada pelos irmãos que comumente só me olham para me colocar para baixo. É difícil para caramba, não tem como não chorar de raiva. Eu penso, "estou aqui dando a minha contribuição e a pessoa não consegue enxergar isso". Então as vezes dá vontade de chutar o pau da barraca e me mandar. Mas aí eu paro, reflito e tenho ciência da responsabilidade da minha missão. 
Em 2009 eu fui presidente do Conselho dos Direitos da Mulher de Salvador e fiquei como conselheira de 2009 a 2013. Nesse intervalo fui candidata em 2010, mas o movimento social não gostou da minha forma de participar da política. Eles saíram e eu fiquei no PV. O partido me convidou para ser candidata à deputada federal. Depois de 2010, fui candidata em 2012. Em 2013 me tornei vice-prefeita de Salvador, onde permaneci até 2016, pelo PV. Em 2014, pelo mesmo partido, fui candidata à vice-presidente da república. No PV fiquei 9 anos, de onde saí em 2015.

Fui para o Partido Pátria Livre (PPL) em 2015, isso para continuar como vice prefeita, mas foi por pouquinho tempo. As candidaturas de 2015 à 2017 foram pelo PPL. Em 2018 entrei na REDE e fui candidata a governadora do estado da Bahia. Eu sai do PPL por um conflito ideológico mesmo, e continuarei na REDE sem dúvida nenhuma. Nesses acordos e junções, acredito que a REDE vai se manter sozinha, mas a REDE e o PSOL se dão bem. Em 2020 serei a primeira prefeita negra de Salvador, escrevam aí. Mas isso se as mulheres negras quiserem, se não...

Pergunta: Quais as pautas que você defende na política?

Célia Sacramento: Minha pauta principal é a educação, depois a inclusão social interseccional das minorias e, por fim, a gestão pública com transparência. Posso defender com uma gestão transparente as mulheres negras, as comunidades indígenas e quilombolas, como também as religiões de matriz africana e comunidade LGBTQI+, não apenas na inclusão social. E com a transformação da educação, você resolve o problema da violência contra a mulher, você resolve todos os problemas. Então acredito que a minha pauta principal é a educação, mas como sou contadora e advogada, o controle na gestão pública e a questão da transparência também são muito presentes. Não tem como pensar em controle e transparência, que são os principais problemas de uma gestão pública, sem ter o olhar para a mulher, para a mulher negra, por exemplo.

Pergunta: O que significa estar na vida política partidária? 
Célia Sacramento: Significa ter condições jurídicas para participar do processo eleitoral, é só isso.

Pergunta: Você acha que existe machismo na política? Quais as suas estratégias para lidar com situações de machismo na política e no cotidiano da vida pública e privada?

Célia Sacramento: Eu não tenho dúvida nenhuma que existe machismo na política e eu provo essa minha afirmativa com a observação do número e gênero das pessoas que são eleitas: na sua maioria homens, apesar das cotas que determinam a obrigatoriedade de 30\% da participação de mulheres, 30\% dos recursos partidários para as mulheres deputadas e vereadoras... Esses 30\% não contemplam a chapa majoritária: prefeitos, governadores e presidentes. Apesar disso, tem todo um contexto de machismo real evidenciado no resultado das eleições.

As cotas nos dizem para participar, mesmo assim nós mulheres não conseguimos. Uma das minhas principais estratégias é estar qualificada como poucas pessoas no Brasil. Então fiz mestrado, doutorado, sou contadora, advogada, especialista em Direito Eleitoral, especialista em planejamento tributário... Só olhando no lattes para saber tudo que sou. Sou vice-presidente da Aliança Global de Prefeitos Líderes e Mandatários até 2024, faço parte do Conselho Permanente de Afrodescendentes da América. Sou conselheira do Conselho Regional de Contabilidade. Minha qualificação é uma primeira estratégia. A segunda estratégia é a disponibilidade para colaborar em tudo, sem nunca ter a exigência do retorno financeiro, por exemplo. Como eu trabalho desde os 16 anos, sempre tive salário, nunca fiquei um dia desempregada. Então pude participar de tudo na militância e na vida política, dando a minha contribuição, colaborando até financeiramente, nunca precisando ganhar nada.

Na vida privada já é diferente, porque nós vivemos na sociedade do capital. Então a estratégia nesse âmbito é alcançar os espaços que garantem o desenvolvimento do trabalho de profissionais, incluindo as pessoas negras. Por exemplo, minhas equipes de trabalho são sempre com pessoas negras. Nos projetos de pesquisa que participo são 500 jovens, um modelo de qualificação para atender as demandas da gestão do conhecimento, e tem 5 brancos. Isso não está escrito formalmente lá, 
"vou trabalhar com recorte racial". Lembrem que na época que comecei a estudar, se você falasse que seu interesse era a questão racial não encontraria um orientador. Por isso que nunca coloquei esse recorte nos meus trabalhos, apesar de ser parte de toda a minha trajetória.

Por exemplo, minha tese de doutorado é toda fundamentada na atividade de consultoria desenvolvida pelos estudantes chamada FVC Consult, da Fundação Visconde de Cairu, onde trabalhei com esses 500 jovens. Eu selecionava os jovens a partir do quinto semestre do curso de contabilidade e administração, para trabalharem como consultores. A partir do sexto semestre eles já eram consultores atendendo profissionalmente, e eu disponibilizava para eles tudo o que existe no Brasil, para se atualizarem na prestação dos serviços de consultoria. Hoje eles estão nas principais empresas e universidades, são autores de livros, diretores na Petrobras, diretores e gestores do Tribunal de Contas, de algumas secretarias, concursados, donos de empresa. Esse projeto inspirou uma amiga, a Lorelay William, uma estadunidense que foi na minha casa há muito tempo, que veio ao Brasil aprender o português. Nesse convívio comigo ela se interessou pelo projeto e questionou, "nesse projeto você não escreve em lugar nenhum sobre a questão racial", e eu respondi, "eu não posso dizer porque senão ninguém vai financiar. A universidade tem mais de 4.0oo alunos e como é que eu vou justificar que na hora de selecionar, porque era eu quem dava a última palavra, eu tirava os brancos mesmo? Que eu deixava uns 5 brancos, só aqueles que eram do gueto?”. E quando perguntavam se só tinham negros no projeto eu dizia que não. Não é assim que eles fazem com a gente? Eu usava a mesma estratégia. Sempre fiz, não só nesse projeto.

Uso essa estratégia desde 1991, na primeira empresa em que fui contadora. Em 1991 fui contadora da empresa de transporte Boa Viagem e da Transportes União. Tinha uma equipe de 6 pessoas, a única branca era a estagiária, os outros todos negros. Então a chefe de pessoal fazia a seleção "universal”, mas como nenhum branco queria fazer seleção para trabalhar comigo, pois sempre encontravam um problema, eu acabava selecionando os negros, mesmo que ainda não soubessem trabalhar. Se eu percebesse que a pessoa tinha vontade de aprender, eu ensinava. Mas era uma estratégia escondida para ter uma equipe de negros, não dava para falar disso abertamente. $\mathrm{E}$ as minhas equipes sempre foram femininas, mais mulheres do que homens. Sempre! Um homem para cada três mulheres. Gosto de trabalhar com as mulheres. Na minha 
equipe tinha uma travesti e uma lésbica. Então desde os 23 anos que eu assumo cargos de chefia, e que tenho condição de escolher com quem vou trabalhar.

Pergunta: O Brasil vivenciou momentos tensos durante o último pleito presidencial. Conte-nos como experienciou este momento significativo para a história do país.

Célia Sacramento: Nossa, tenho que ser bem objetiva. Esse processo eleitoral foi um verdadeiro Brasil mostre a sua cara, e o Brasil mostrou que é machista, racista, elitista, xenofóbico. Para mim não foi uma revolta das pessoas, o Brasil mostrou a sua verdadeira cara. Pela primeira vez a Bahia teve uma candidata negra para o governo do estado e não votou nela. As pessoas me disseram, "Célia, você foi candidata a governadora mesmo sabendo que não ia ser eleita?”. Eu não sabia que não ia ser eleita. Quis fazer intervenção social. O que as pessoas tiveram de desculpa para não votar em mim e votar em Rui? Não tiveram! É porque não sou qualificada? Não tenho experiência? Fui vice-prefeita de Salvador e fiquei exclusivamente na cadeira de vice-prefeita, ganhando menos, tendo dividido ao meio o meu padrão financeiro de vida. Poderia ter assumido uma secretaria, continuar dando aula, que teria um salário 3x maior do que o de vice-prefeita. Preferi sacrificar a minha família, reduzir o meu padrão, porque queria aprender a gestão por dentro. É diferente ser o executor político da gestão do que ser de fora, como uma consultora. Nesses 4 anos, trabalhei, chegava no gabinete 7 h3omin da manhã e só saía as 21h. Quantas vezes o Prefeito e eu íamos inaugurar obras as $7-8$ horas da manhã!

Nunca briguei com o prefeito. O nosso único problema foi quando ele disse que eu não iria ser vice-prefeita de novo. Eu apenas disse, "tudo bem prefeito, você toca o seu projeto, que eu toco o meu". E ele me respondeu, "não Célia, te dou uma secretaria, faço a sua candidatura para deputada federal". Respondi a ele que meu projeto era a gestão. No PV eu estava brigando com uma candidata branca riquíssima, que queria ser a candidata a prefeita. Eu sabia que ia perder, mas não tem nada não, decidi concorrer. Foi uma experiência bacana ser uma vice-prefeita. Todas as coisas que pude fazer para a comunidade, para o movimento social, regularizei todas as entidades, por exemplo. 
Nessa eleição tivemos a entrada de um mecanismo tecnológico no processo eleitoral, incontrolável pelas legislações, que foram as mídias sociais. As mídias sociais fizeram a diferença a partir do momento que elas possibilitaram que qualquer pessoa pudesse promover alguém, dando visibilidade a essa pessoa através de um pagamento financeiro. Meu Facebook tem sei lá, uns $15 \mathrm{mil}, 16 \mathrm{mil}$ seguidores, mas as pessoas não curtem as postagens, não comentam. Quando chego em um lugar sempre me perguntam, "você estava não sei aonde né?”. As pessoas acompanham a sua vida, mas não interagem. Como é que a legislação vai consegui controlar isso aí?

Se nós quisermos alcançar o poder, nós vamos precisar conseguir parceiros, para fazer essas promoções dos candidatos nas mídias sociais. Isso é algo que mais uma vez vai nos separar, porque é quem tem mais dinheiro que vai conseguir. Então quando o candidato que ganhou a presidência da república dizia, "eu sou a favor das armas", ele estava falando para a indústria armamentista promovê-lo. Então a indústria vinha e colocava dinheiro. Cada coisa que ele falava atingia um nicho. $\mathrm{Eu}$ entrei para ver a prestação de contas dele e foram 4 milhões! A minha campanha para governadora foi de 50 mil, a de Haddad foram 34 milhões!

Pergunta: Como encara o debate sobre gênero e sexualidade tão reivindicado e usado nos últimos anos no cenário político brasileiro?

Célia Sacramento: Existe uma desproporção na política partidária entre homens e mulheres. Acabei de fazer uma pesquisa com uma orientanda aqui na Bahia, e acho que essa pesquisa se reflete no Brasil. Existe uma manipulação que os partidos tem feito. Constatei, entrando em cada ata dos partidos, que nem sempre cumprem os $30 \%$. Mas a legislação fala que os 30\% são por partido ou coligação, e daí eles fazem uma coligação com os partidos pequenos, pedem para esses partidos colocarem as mulheres e os partidos grandes, que tem o dinheiro, continuam concentrando o dinheiro nos homens. A gente não consegue enxergar isso aí, eles usam uma série de estratégias para fazer de conta que estão atendendo as nossas reivindicações e os nossos sonhos, mas na verdade não estão atendendo quaisquer reivindicações nossas. Entendo, principalmente depois das políticas públicas que foram construídas no governo Lula e Dilma, que uma grande quantidade de 
pessoas se assumem integrantes da comunidade LGBTQI+. Isso facilita para identificar as necessidades e demandas dessa população. Percebo, principalmente no ambiente universitário e no ensino médio, que os jovens estão cada vez mais se declarando integrantes da comunidade LGBTQI+, o que requer uma atenção particularizada do gestor. Então percebo a necessidade de construção de políticas públicas que tenham atenção a essa população, não tenho como pauta, mas serei sempre defensora de todas as demandas do movimento social como um todo, inclusive aquelas da comunidade LGBTQI+.

Pergunta: Você acha que o discurso do presidente eleito autorizou ações violentas sobre o corpo da mulher, dos LGBTQI+, dos negros/as, nordestinos/as?

Célia Sacramento: Não tenho dúvida que autorizou! O presidente da república falou coisas que muitos brasileiros queriam ter falado, assim como Hitler usou da sua condição de líder para comandar o holocausto. Ele fez com a anuência da população! Quando Bolsonaro se apresenta com determinados posicionamentos, ele tem o respaldo da população que votou nele. Ele dá essa carta branca! Mais uma vez, se nós não estivermos unidos, não vamos ter como superar isso. Vamos ver que ele é atrelado com integrantes de igrejas protestantes, que também são favoráveis a esse posicionamento dele usando o argumento da defesa da família.

Só se estivermos unidos poderemos superar esse momento e vencer esse embate dele. Temos que usar da mesma estratégia que ele usou para ser eleito, colocarmos nossas pautas na mídia, mostrar o que está acontecendo, darmos visibilidade ao que pensamos e defendemos. As pessoas são racistas, mas não querem que digamos que são. Você via que, por muitas vezes, ele se contradizia. Ele é assim mesmo, sabe que é assim e tem muita gente que pensa igual a ele. Enquanto negros, somos a maioria da população. Sempre fomos excluídos, mas a gente nunca reclamou, pelo menos naqueles mecanismos que nos dão condições de superar, ou seja, no poder. Nós reclamamos gritando, cantando, panfletando... Temos que parar de agir só assim. A gente só vai conseguir a verdadeira transformação quando nos elegermos. É só esse o caminho, não tem jeito. Aí uma vez no poder político a gente consegue mudar a educação, vamos conseguir mudar tudo. 
Pergunta: Como observa a participação das mulheres brasileiras em cargos políticos ou de decisão?

Célia Sacramento: As pesquisas sinalizam que no ambiente empresarial as mulheres estão ganhando cerca de $28 \%$ a menos do que os homens, mesmo estando mais qualificadas. Não sou eu que estou afirmando não, são as pesquisas, é real! Mesmo estando mais qualificadas! E no espaço do poder político as mulheres, de uma forma geral, eram $11 \%$ e agora, a partir do próximo pleito eleitoral, vão para $14 \%$. Só que isso não se reverbera nas mulheres negras que não chegam a ser um 1\% das eleitas no Brasil, ou seja, ou a gente toma consciência e para de ficar procurando defeito nas mulheres negras, ao invés de colocá-las no poder, ou nunca alcançaremos a igualdade! E ainda tem gente que diz que não adianta ser mulher negra, tem que me representar. Dizem, "Rui me representa mais do que ela", então tá!

Pergunta: Qual o papel da oposição no atual cenário político?

Célia Sacramento: O Brasil na última eleição definiu o que é oposição. Oposição não é aquilo que nós entendíamos quando o PT estava no poder. A oposição era o PSOL, eram os professores e também eram os partidos que não estavam no poder. Nesse processo eleitoral não. A oposição hoje é o PT, é como se só existisse essa oposição no Brasil. As pessoas só conseguem entender assim. Os outros partidos que se diziam de oposição não conseguem se comunicar, inclusive a REDE. Falam que somos muito radicais, que a REDE é muito ambiental e que quem sabe fazer oposição de verdade é o PT. O PCdoB é igual ao PT, ambos se misturam. Então para mim o papel da oposição atual é defender toda a perda de direitos que já começou no governo Temer e que virá com mais força nesse governo.

Pergunta: Qual a sua concepção sobre a esquerda na política brasileira? 
Célia Sacramento: A minha concepção é a mesma, que direita são aqueles que não defendem os interesses do povo, e não importa se eles estão ou não no poder. Então mesmo o PT estando no poder, ele foi esquerda. Entendo que no Brasil é diferente da Europa. Quando se fala em direita e esquerda, se fala em relação a quem está no poder. $\mathrm{Na}$ Europa essa história de esquerda e direita foi criada em relação a quem está no poder. Já no Brasil, direita e esquerda está relacionada a quem defende o povo, quem defende os direitos do povo. E aí vamos falar do PT, do PCdoB, do PSOL, alguns integrantes da REDE. Ser esquerda é isso, é defender os direitos do povo. O centro são aqueles que defendem os interesses do povo mas que atrelam o interesse do povo ao desenvolvimento do país.

Pergunta: O que pensa sobre o Brasil de hoje?

Célia Sacramento: O Brasil de hoje espera mudanças profundas ao que foi posto. É um Brasil que quer de fato que se acabe com a corrupção, que foi uma coisa que ficou muito marcada em nosso país. Já vi pessoas indignadas com o PT, mesmo pessoas que sempre apoiaram esse partido. O Brasil de hoje quer muito o que é certo, correto. O Brasil quer uma mudança, mas não soube votar.

Pergunta: Quais os seus planos para a política de agora em diante?

Célia Sacramento: Vou fazer o que tenho feito desde quando eu entrei na militância. Falei no início que a minha vida na política iniciou muito jovem, na política estudantil, no Diretório Acadêmico da UFBA, da Fundação Visconde de Cairu, nos grêmios de todas as escolas onde estudei, na associação de bairro, no movimento negro, pois fui da juventude do Movimento Negro Unificado (MNU)... Inclusive eu tenho uma foto minha no dia da inauguração da sede do MNU. Tem gente por aí que quer negar a minha participação no movimento negro, ou em qualquer movimento social. Eu participei das discussões das diretas, fui à Brasília representando a Federação das Associações de Bairros de Salvador (FABS). Nessa viagem, que fui graças à Antônia Garcia, participamos de uma discussão sobre a constituição que queríamos. 
Antônia reuniu todas as associações de bairro que ela pôde em Salvador, para irmos em caravana à Brasília. Chegando lá tinha ônibus do Brasil inteiro. Eu fui a pessoa encarregada de nossa delegação para entregar o documento da Bahia para Ulisses Guimarães. Eu tinha 16 anos, saí na televisão. Então mesmo que queiram negar a minha história, é só procurar! Vou continuar fazendo o que sempre fiz, me dedicar, me doar, porque não tenho retorno financeiro nessa história de militância política, pelo contrário! Tenho perda familiar! A minha última separação foi justamente quando fiz a aliança com ACM Neto. Ele ficou revoltado, o casamento já não estava bom, mas daria para segurar, mas ele aproveitou a situação e disse, “chega!”. Mas é bom renovar...

Agora as rapidinhas. Um livro? Maria Helena Gonçalves Um defeito de Cor. Eu gosto tanto desse livro que todas as minhas amigas quando sei a data do aniversário, dou esse livro de presente.

Uma música? Estrada - Cidade Negra, e gosto de outra da juventude que é Esquinas - Djavan, "sabe lá o que é não ter, e ter que ter para dar", que representa a mulher, a mãe, a única capaz de mesmo estando com fome, abrir mão do alimento, dar para o filho e ver ele se alimentando.

Uma frase? “Apesar de tudo, tudo, tudo, sucesso total!”.

Célia Sacramento: Eu não contei para vocês o drama da minha vida, que foi a morte da minha mãe. Vocês já sabem a minha luta para entrar na UFBA, e no dia da minha primeira aula, que foi na sala da congregação, uma aula bacana, liguei para minha mãe e perguntei, "e ai minha mãe está vindo?", e ela respondeu, "Célia, se toque porque estudante universitária anda sozinha, a mãe não busca no primeiro dia de aula não, e você decida, porque tá chovendo". Quando chovia eu ia para a casa da minha Tia Terezinha, porque minha rua enchia de lama. Fui para essa aula inaugural, cheguei em casa e nem mudei de roupa, me joguei no sofá para descansar. Um pouco depois meu irmão chega com a notícia que minha mãe tinha falecido. Um grupo de jovens estava usando drogas e tentou assaltá-la. Quando a reconheceram houve uma luta corporal e ela enfartou e morreu. Então no dia que conquistei o sonho de 
entrar na universidade também perdi a minha mãe. Ganhei uma coisa e perdi outra.

Outro livro que me marcou muito é de Daniel Goleman Inteligência Emocional. Uma amiga de minha mãe era muito ativa, e eu muito briguenta. Brigava com homens ou mulheres, não tinha nenhuma diferença para mim. E essa amiga psicóloga disse, "Célia, não é o QI que faz a diferença na vida das pessoas, tem muitas pessoas inteligentes que não conseguem se dar bem na vida profissional por causa do emocional". E me deu uma revistinha da companhia aérea Varig com o artigo desse cara. De lá tirei uma estratégia sobre como viver no mundo da política e no mundo machista: a inteligência emocional.

Um sonho? Ver uma mulher negra no poder, uma mulher, não precisa ser eu não, no poder da cidade de Salvador. É um sonho da juventude. E não é um sonho só meu, é um sonho que a gente discutiu, que a gente planejou. E quando o movimento social foi me buscar para a política, eu só lembrava disso! Eu disse para juventude que não ia ficar com essa missão e ela bateu na minha porta. Por isso estou na política com tanta dedicação. E tenho esse sonho, e digo que fico aqui só participando, enfrentando. Pode até não ser eu, mas pode ser a sua filha [apontando para a entrevistadora Shirlei] ou a filha de Keila [em referência à sua futura neta].

Espero que um dia todos possam ver a importância da mulher negra na política. Precisamos falar mais que nós mulheres precisamos conquistar esse espaço de poder, nós precisamos entender isso. E vocês da academia tem um papel fundamental. Eu tive pela primeira vez 30 mil votos, são votos para caramba! Estou muito agradecida, até postei no meu facebook. Tive votos em todas as regiões da Bahia, e tive esses votos porque sou contadora, pois foi a minha classe profissional que se jogou na campanha, muitos professores universitários de várias áreas e muitas mulheres negras também. Espero mesmo que a gente adquira essa consciência, a partir de trabalhos como esse que vocês estão fazendo, sucesso total! 